\title{
SHORT COMMUNICATION \\ COMPARISON OF OFFICIAL FOOD SAFETY CONTROL SYSTEMS IN MEMBER STATES OF THE EUROPEAN UNION
}

\author{
Pavla Svrčinová, Vladimír Janout \\ Department of Epidemiology and Public Health, University of Ostrava, Ostrava, Czech Republic
}

\section{SUMMARY}

In recent years increasing pressure to limit the powers of the Czech public health authorities in the field of food safety has been noticed. An approach to safe food production and official controls depends on diverse and complex socioeconomic factors in the context of political and legislative framework within which food producers and official controllers exist. Official controls are those activities carried out by the competent authorities (CA) or delegated bodies) in Member States to verify business compliance with the requirements set out in agri-food chain legislation. The presented text compares the effectiveness of national food safety systems in the Member States (MS) of the European Union (EU). Under the current EU legislation, each MS shall appoint the competent authorities responsible for the purposes of European legislation in the field of food safety and for performance of official controls. Member States shall ensure that official controls are carried out regularly, on a risk basis and with appropriate frequency to achieve the objectives set out in the European legislation. For evaluation were used the country profiles of Member States, as published in 2011-2015. From the perspective of the European Commission current system of official controls in the Czech Republic is rated as one of the most effective and least problematic. When comparing various systems in Member States it is not possible to decide which control system is more efficient, i.e. system based on one competent authority or relying on several competent authorities.

Key words: system of official controls, food safety, European Union, member states, effectiveness

Address for correspondence: P. Svrčinová, University of Ostrava, Faculty of Medicine, Department of Epidemiology and Public Health, Syllabova 19, 70300 Ostrava, Czech Republic. E-mail: pavla.svrcinova@osu.cz

https://doi.org/10.21101/cejph.24940

\section{INTRODUCTION}

The Article 3 of Regulation (EC) No. 882/2004 of the European Parliament and of the Council of 29 April 2004 on official controls performed to ensure compliance with feed and food law, animal health and animal welfare rules states, that the Member States of the European Union shall ensure that official checks are carried out regularly, on a risk basis and with appropriate frequency to achieve the provision of safe and wholesome food and feeds. Recently, efforts are undertaken to change the food safety control system in the Czech Republic (1). The European Commission enforces EU food law by checking that Member States incorporate EU legislation into their national law and implement it correctly, while national agencies are responsible for ensuring that $\mathrm{EU}$ rules are respected (2). The presented text is intended to help policy makers, officials on different levels of the state administration operating in the field of food safety, to assess the advantages and disadvantages of different systems of official controls as applied by the Member States of the European Union.

\section{MATERIALS AND METHODS}

According to Article 45 of Regulation (EC) No. 882/2004 are audits carried out by experts of the Commission in the Member States (3). Audits are carried out regularly. Their main purpose is to verify whether the official controls in Member States are performed in accordance with Multi-Annual National Control Plans and in compliance with Community legislation. The general audits may be supplemented by specific audits and inspections in one or more specific areas. These specific audits and inspections shall investigate important or recurring problems in Member States and to investigate emergency situations, emerging problems or new developments in Member States. Existing legislation in the field of food does not provide procedures for assessing the effectiveness of control systems of food safety in the Member States of the European Community. The assessment of control systems in Member States handles Directorate F (FVO) of the Directorate General for Health and Consumer Protection of the European Commission (DG SANTE) in the so-called country profile (CP), 
which are published on the website of the European Commission. The article compares the effectiveness of official controls over food safety in Member States, as basis for comparison were chosen country profiles of all member states published on the website of the European Commission in 2011-2015.

\section{RESULTS}

For basic evaluation of the food safety control systems effectiveness was used total number of FVO audits, indicating that the FVO in some Member States had to carry out not only regular general audits but also audits to investigate recurring and serious problems with the functioning of control systems. Within this indicator the Czech Republic was ranked slightly above the EU average (Fig. 1).

According to Regulation (EC) No. 882/2004, the Commission shall submit a report on the results of each audit carried out. Such report, if necessary, contains recommendations for Member States on how to improve compliance with feed and food, animal health and animal welfare legislation. The Commission shall make its report available to the public. In case of reports on controls carried out in a Member State, the Commission provides the competent authority with a draft report for comments and these comments are taken into account when preparing the final report. Comments are published together with the final report on the web pages of the European Commission. Member States shall, on the basis of the recommendations, take follow-up actions to improve situation. The effectiveness of control systems can be compared on the basis of the number of recommendations from audits of the official control systems. The evaluation was made on the basis of the number of recommendations per one audit. Top-ranked

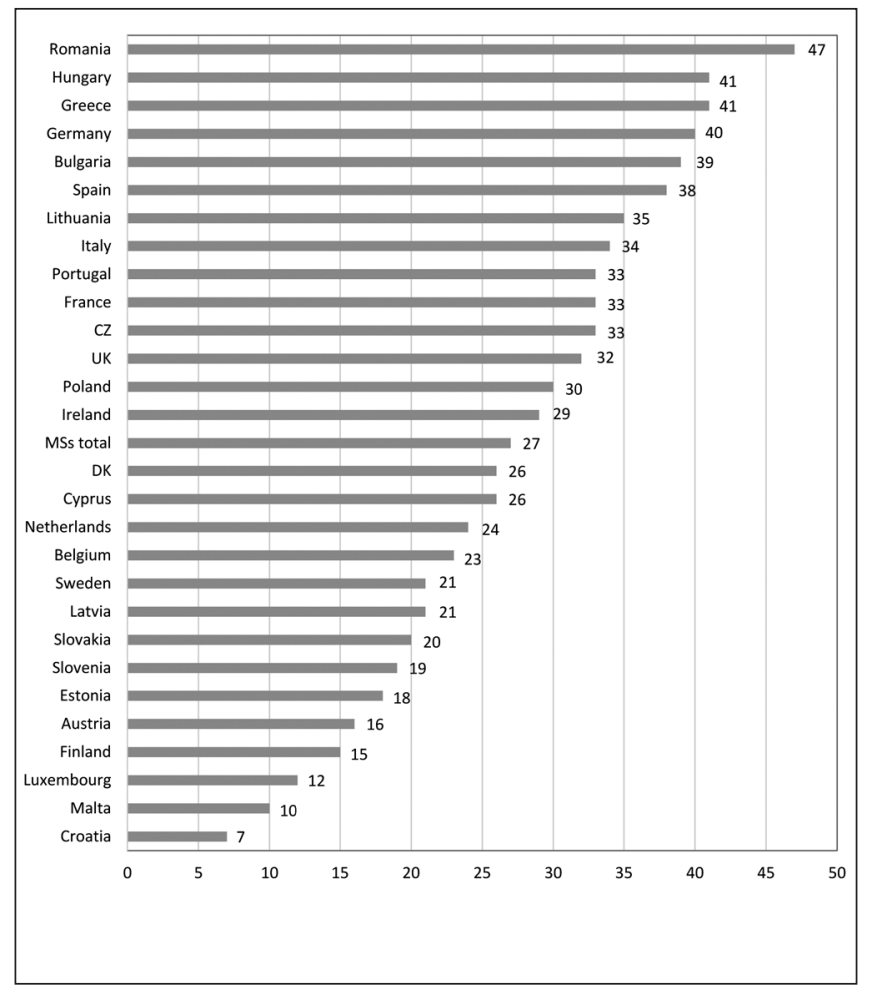

Fig. 1. Comparison of the total number of FVO audits.

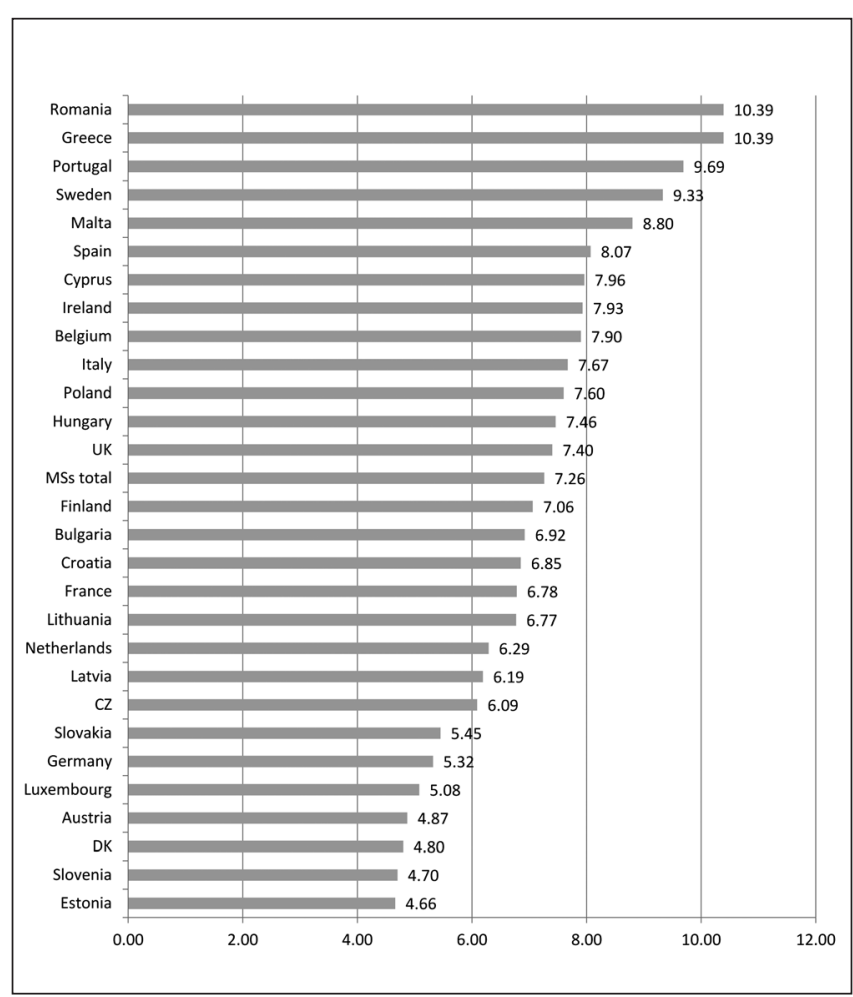

Fig. 2. Number of recommendations per 1 FVO audit.

Member State in this respect is Estonia (1 competent ministry). Second is Slovenia (4 competent ministries). The Czech Republic is ranked 8 th ( 2 competent ministries) with 6.09 recommendations per one audit. According to this indicator the Czech Republic system is between the three best countries. The EU average is 7.26 recommendations (Fig. 2).

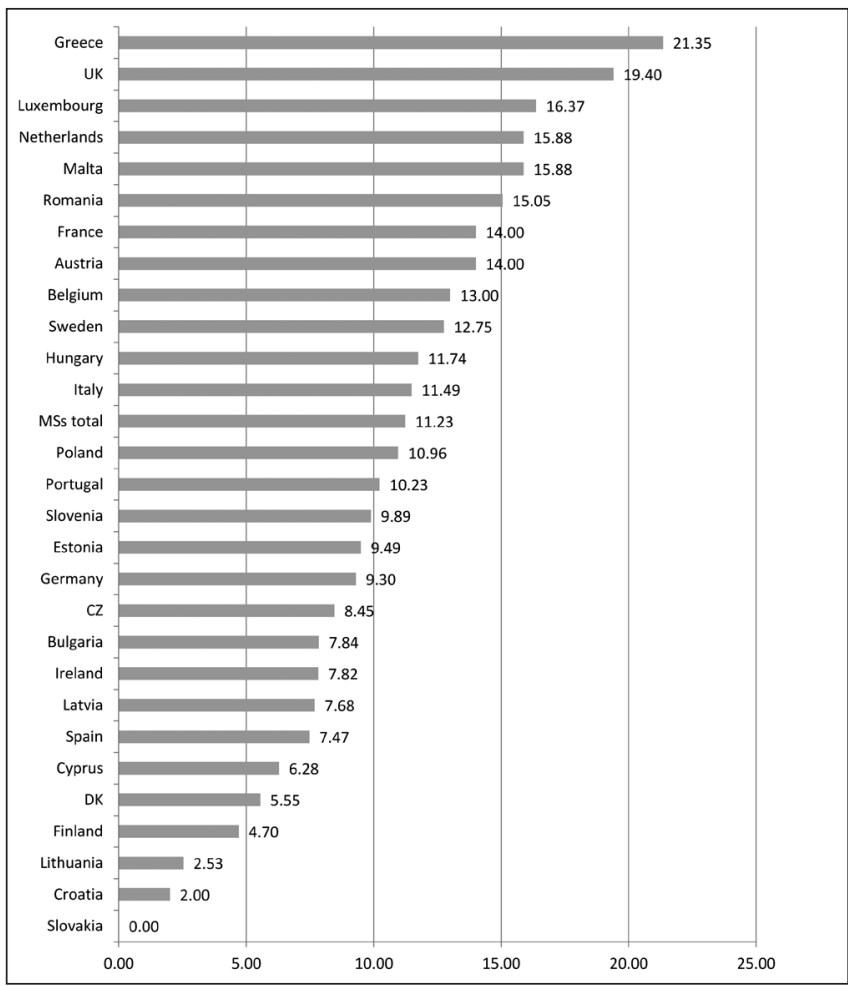

Fig. 3. Number of not addressed recommendations made by European Commission. 


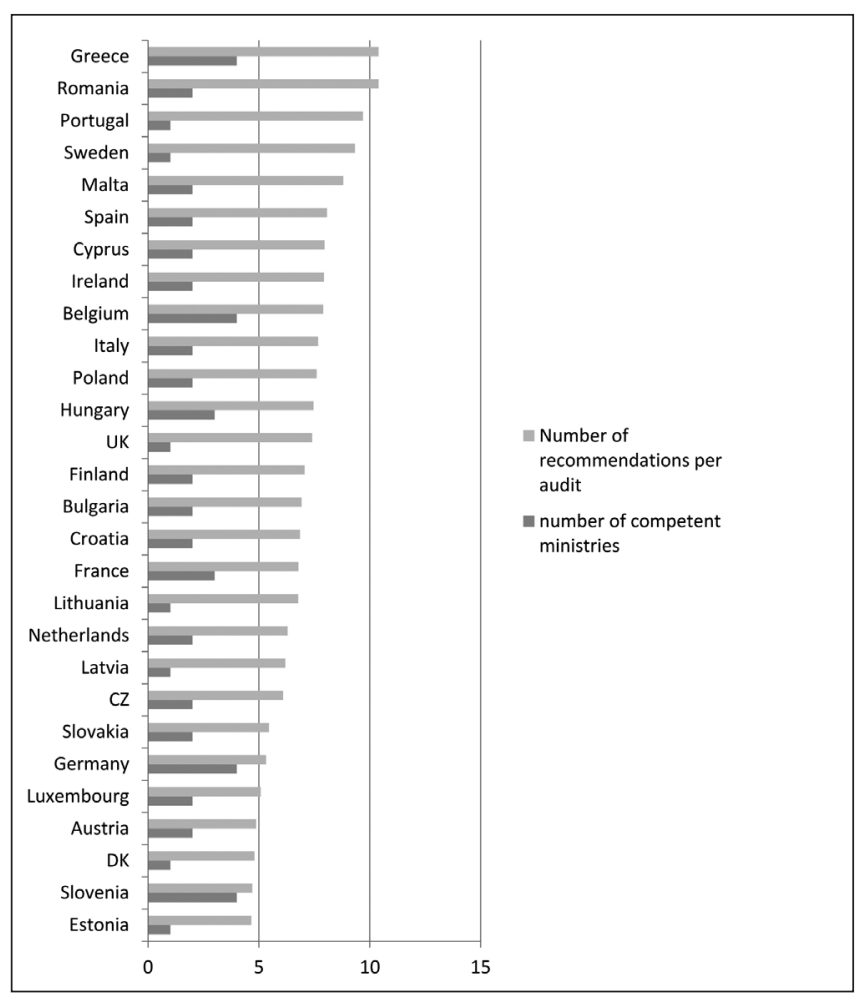

Fig. 4. Comparison between number of competent ministries and number of recommendations per audit.

Another criterion for evaluating Member States was improvement and changes in the official control systems to meet the recommendations of the Commission. The best Member State in this evaluation is Slovakia with no unfulfilled recommendations ( 2 competent ministries) and Croatia ( 2 competent ministries) with $2 \%$ of unsatisfactorily or only partially addressed recommendations. On the other side of the range is Greece (4 competent ministries $)-21.35 \%$ and the UK ( 1 competent ministry) $-19.4 \%$ of outstanding recommendations of the European Commission. In this evaluation, the Czech Republic finished on 11th place with $8.45 \%$ not fully addressed recommendations made by the European Commission. Average for the EU as a whole is $11.23 \%$ of outstanding recommendations (Fig. 3).

As the next step was made assessment of the number of ministries responsible for carrying out official controls in the field of food safety. Responsible competent ministry or ministries are established in all Member States, as provided for in Article 2 of Regulation (EC) No. 882/2004 (Table 1). Only in one Member State is not under the control system incorporated the Ministry of Health (MH) - Germany, three Member States do not have in the control system Ministry of Agriculture and Rural Development (MA) Malta, the Netherlands and Sweden. Six Member States (Denmark, Estonia, Lithuania, Latvia, the United Kingdom of Great Britain and Northern Ireland (UK), and Portugal) has only one supervisory authority, out of these in two Member States it is Agency under the direct control of the government - Lithuania and the UK.

Figure 4 shows the number of recommendations per audit related to the number of competent Ministries. The figure shows that the effectiveness of the control systems of food safety is not affected by the number of ministries responsible under national legislation for food safety. There is also no difference between the Member States where the main responsible ministry is the Min-
Table 1. Number of competent ministries in Member States

\begin{tabular}{|l|c|}
\hline Member State & Number of competent ministries \\
\hline Bulgaria & 1 \\
\hline Denmark & 1 \\
\hline Estonia & 1 \\
\hline Latvia & 1 \\
\hline Lithuania & 1 \\
\hline Portugal & 1 \\
\hline Sweden & 1 \\
\hline United Kingdom & 1 \\
\hline Austria & 2 \\
\hline Croatia & 2 \\
\hline Cyprus & 2 \\
\hline Czech Republic & 2 \\
\hline Finland & 2 \\
\hline Ireland & 2 \\
\hline Italy & 2 \\
\hline Luxembourg & 2 \\
\hline Malta & 2 \\
\hline Netherlands & 2 \\
\hline Poland & 2 \\
\hline Romania & 2 \\
\hline Slovakia & 2 \\
\hline Spain & 2 \\
\hline France & 2 \\
\hline Hungary & 2 \\
\hline Belgium & 2 \\
\hline Germany & 2 \\
\hline Greece & 2 \\
\hline Slovenia & 2 \\
\hline
\end{tabular}

istry of Agriculture (Romania, Slovenia and the Czech Republic) or the Ministry of Health (Austria, Ireland).

If the Ministry of Health leads the food safety control system, its supervision covers the most of the food chain. If the Ministry of Health is not leading supervisory authority, its activities include in particular the supervision of health threats (7 Member States), catering, supplements, food hygiene, and food for particular nutritional uses (5 Member States). The food contact materials, chain for food of non-animal origin and water, including mineral and bottled, are covered by the Ministry of Health in 4 Member States.

\section{DISCUSSION}

The shift of the modern food safety conception from "reactive" to "preventive", has led governments world-wide moving towards risk-based approaches to food control and requiring all operators in the food supply chain to share responsibility for food safety. This in particular requires food inspection programmes to prioritize controls based on risks posed by the food or food operator practices (4). 
Official food control may be considered one of the corner stones in producing safe food and promoting public health, but its efficacy is something that may not be taken as self-evident. No effective methods yet exist for evaluating the true impact of food control on food safety. Epidemiologic data on food-related illnesses may be applied for evaluating the impact of food safety control plans, but since the majority of food poisonings are restaurant-derived epidemics, this method is not directly applicable at the level of food-processing plants. In some cases, the evaluation of non-compliances by an inspector, as being relevant in terms of food safety, may yet vary due to diversity in the educational background of inspectors (5).

It is difficult to estimate the burden of foodborne diseases: only a small fraction is recognized by concerned authorities. The ultimate goal of food safety and public health officials is to prevent such outbreaks. Surveillance systems allow authorities to better understand major food safety risks and to refocus prevention efforts. It also allows early detection of adverse food safety events and prompt and effective response (4). The national food safety control system should be designed to manage emergencies and unpredictable situations (3).

To ensure efficient and effective use of resources controls should focus on those areas and activities where the risk (including risk of non-compliance) is higher. To this end Member States competent authorities must take into account the risk to human, animal or plant health, animal welfare or the environment (for genetically modified products and plant protection products) associated with animals or goods (6).

From that point of view, it seems that staff of the Ministry of Health could have advantage in their university studies that included subjects as pathophysiology, epidemiology and preventive medicine, including risk assessment. The advantage of the Ministry of Health could be seen also in the direct access to the data about outbreaks and poisonings that shortens period to react to emergencies. However, results of our study did not verify this assumption.

A framework for collaboration is necessary at national and international levels, with clear roles and responsibilities (7).

Cooperation and collaboration between competent authorities could play crucial role in the effectiveness of the official control system. Cooperation is the basic requirement of Regulation (EC) No 882/2004. When a Member State confers the competence to carry out official controls on an authority or authorities other than a central competent authority, in particular those at regional or local level, efficient and effective coordination shall be ensured between all the competent authorities involved (8).

A number of competent authorities (CA) met considered that defining and measuring effectiveness of official controls posed a significant challenge (9).

The authors are aware that the study was carried out on the basis of documents which were prepared for individual Member States by different auditors with slightly different approach to the assessment of audit results. Additionally, the country profiles were processed over a relatively long period of time, the basic structure of a country profile was the same, however, it differs in detail, therefore, all parts of the country profiles could not be evaluated. This is one of the first studies trying to assess the effectiveness of the food safety official control systems in Member States and it would be advisable to repeat such study. A reassessment in the future could be done after upgrading of country profiles (10-37). It is advisable to compare trends in the audits results of the Czech official control system and analyze them, as they reveal developments in the official control system. The Czech system could be compared with systems of official controls in other Member States.

It would be beneficial if next study covers also further aspect such as coordination and cooperation between competent authorities, background and training of the staff. It would be beneficial to accompany it by the view of stakeholders in the Czech Republic on functioning of the official control system.

\section{CONCLUSIONS}

Based on the data available it can be concluded that it is impossible to assess one control system as more effective than the other. The control system in the field of food safety, as established in the Czech Republic under the applicable legislation before the end of 2014, is assessed at the level of the European Union as functioning very well and exceptionally powerful, covering all relevant legislation on the European level.

\section{Conflict of Interests}

None declared

\section{REFERENCES}

1. Radakovic M. Food safety - flexible approaches to production and official controls. Procedia Food Sci. 2015;5:247-9.

2. European Union. Food safety [Internet]. [cited 2018 Dec 14]. Available from: https://publications.europa.eu/en/publication-detail/-/ publication/0db60b7e-63b3-11e8-ab9c-01aa75ed71a1/language-en/ format-PDF/source-82688996.

3. Shukla S, Singh SP, Shankar R. Evaluating elements of national food control system: Indian context. Food Control. 2018;90:121-30.

4. Improving food safety and quality along the chain to protect public health, support fair food trade and contribute to food security and economic development [Internet]. FAO; 2012 [cited 2018 Dec 14]. Available from: http://www.fao.org/fsnforum/resources/fsn-resources/improving-foodsafety-and-quality-along-chain-protect-public-health-support.

5. Nevas M, Kalenius S, Laudén J. Significance of official food control in food safety: Food business operators' perceptions. Food Control. 2013;31(1):59-64

6. Questions \& answers on Commission Regulation (EC) No 2017/625 (Official Controls Regulation) [Internet]. EU; 2017 [cited 2018 Dec 14]. Available from: https://ec.europa.eu/food/sites/food/files/safety/docs/ oc_qa_ocregulation_20170407_en.pdf.

7. FAO; $\overline{\mathrm{O} I E}$; WHO. Sharing responsibilities and coordinating global activities to address health risks at the animal-human-ecosystems interfaces: a tripartite concept note [Internet]. FAO; 2010 [cited 2018 Dec 14]. Available from: https://www.who.int/influenza/resources/documents/ tripartite_concept_note_hanoi/en/.

8. Regulation (EC) No $882 / 2004$ of the European Parliament and of the Council of 29 April 2004 on official controls performed to ensure the verification of compliance with feed and food law, animal health and animal welfare rules. Off J Eur Union. 2004 Apr 30;47(L 165):1-141.

9. European Commission. Overview report of a series of FVO fact - finding, missions and audits carried out in 2012 and 2013 in order to evaluate the systems put in place to give effect to article 8(3) of Regulation (EC) No 882/2004 of the European Parliament and of the Council [Internet]. [cited 2018 Dec 14]. Available from: http://www.google.cz/url?sa=t $\& \mathrm{rct}=\mathrm{j} \& \mathrm{q}=\&$ esrc $=\mathrm{s} \&$ source $=$ web $\& \mathrm{~cd}=1 \& \mathrm{ved}=2 \mathrm{ahUKEwiz} 9 \mathrm{cq} 1 \mathrm{Jrf}$ AhXRKFAKHQanAnUQFjAAegQICRAC\&url=http $\% 3 \mathrm{~A} \% 2 \mathrm{~F} \% 2 \mathrm{~F}$ ec.europa.eu $\% 2 \mathrm{Ffood} \% 2 \mathrm{Ffvo} \% 2 \mathrm{Foverview}$ reports $\% 2 \mathrm{Fact}$ getPDF. cfm\%3FPDF_ID\%3D146\&usg=AOvVaw0lkbOviYqik4jC7EZu_sAp. 
10. European Commission. Food. Country profile-Austria. [Internet]. [cited 2018 Dec 14]. Available from: http://ec.europa.eu/food/audits-analysis/ country profiles/details.cfm?co id=AT.

11. European Commission. Food. Country profile-Belgium [Internet]. [cited 2018 Dec 14]. Available from: http://ec.europa.eu/food/audits-analysis/ country_profiles/details.cfm?co_id=BE.

12. European Commission. Food. Country profile-Bulgaria [Internet]. [cited 2018 Dec 14]. Available from: http://ec.europa.eu/food/audits-analysis/ country_profiles/details.cfm?co_id=BG.

13. European Commission. Food. Country profile - Croatia [Internet]. [cited 2018 Dec 14]. Available from: http://ec.europa.eu/food/audits-analysis/ country profiles/details.cfm?co id=HR.

14. European Commission. Food. Country profile-Cyprus [Internet]. [cited 2018 Dec 14]. Available from: http://ec.europa.eu/food/audits-analysis/ country_profiles/details.cfm?co_id=CY.

15. European Commission. Food. Country profile-Czech republic [Internet]. [cited 2018 Dec 14]. Available from: http://ec.europa.eu/food/auditsanalysis/country_profiles/details.cfm?co_id $=\mathrm{CZ}$.

16. European Commission. Food. Country profile-Denmark [Internet]. [cited 2018 Dec 14]. Available from: http://ec.europa.eu/food/audits-analysis/ country_profiles/details.cfm?co_id=DK

17. European Commission. Food. Country profile - Estonia [Internet]. [cited 2018 Dec 14]. Available from: http://ec.europa.eu/food/audits-analysis/ country_profiles/details.cfm?co_id=EE.

18. European Commission. Food. Country profile - Finland [Internet]. [cited 2018 Dec 14]. Available from: http://ec.europa.eu/food/audits-analysis/ country_profiles/details.cfm?co_id=FI.

19. European Commission. Food. Country profile - France [Internet]. [cited 2018 Dec 14]. Available from: http://ec.europa.eu/food/audits-analysis/ country profiles/details.cfm?co id=FR.

20. European Commission. Food. Country profile-Germany [Internet]. [cited 2018 Dec 14]. Available from: http://ec.europa.eu/food/audits-analysis/ country_profiles/details.cfm?co_id=DE.

21. European Commission. Food. Country profile - Greece [Internet]. [cited 2018 Dec 14]. Available from: http://ec.europa.eu/food/audits-analysis/ country_profiles/details.cfm?co_id=GR.

22. European Commission. Food. Country profile-Hungary [Internet]. [cited 2018 Dec 14]. Available from: http://ec.europa.eu/food/audits-analysis/ country profiles/details.cfm?co id=HU.

23. European Commission. Food. Country profile $\neg-$ Ireland [Internet]. [cited 2018 Dec 14]. Available from: http://ec.europa.eu/food/audits-analysis/ country_profiles/details.cfm?co_id=IE.

24. European Commission. Food. Country profile - Italy [Internet]. [cited 2018 Dec 14]. Available from: http://ec.europa.eu/food/audits-analysis/ country_profiles/details.cfm?co_id=IT.
25. European Commission. Food. Country profile - Latvia [Internet]. [cited 2018 Dec 14]. Available from: http://ec.europa.eu/food/audits-analysis/ country profiles/details.cfm?co id=LV.

26. European Commission. Food. $\bar{C}$ ountry profile - Lithuania [Internet]. [cited 2018 Dec 14]. Available from: http://ec.europa.eu/food/auditsanalysis/country_profiles/details.cfm?co_id=LT.

27. European Commission. Food. Country profile - Luxembourg [Internet] [cited 2018 Dec 14]. Available from: http://ec.europa.eu/food/auditsanalysis/country_profiles/details.cfm?co_id=LU.

28. European Commission. Food. Country profile - Malta [Internet]. [cited 2018 Dec 14]. Available from: http://ec.europa.eu/food/audits-analysis/ country profiles/details.cfm?co id=MT.

29. European Commission. Food. Country profile - Netherlands [Internet]. [cited 2018 Dec 14]. Available from: http://ec.europa.eu/food/auditsanalysis/country_profiles/details.cfm?co_id=NL.

30. European Commission. Food. Country profile-Poland [Internet]. [cited 2018 Dec 14]. Available from: http://ec.europa.eu/food/audits-analysis/ country_profiles/details.cfm?co_id=PL.

31. European Commission. Food. Country profile - Portugal [Internet]. [cited 2018 Dec 14]. Available from: http://ec.europa.eu/food/audits-analysis/ country profiles/details.cfm?co id=PT.

32. European Commission. Food. Country profile - Romania [Internet]. [cited 2018 Dec 14]. Available from: http://ec.europa.eu/food/audits-analysis/ country_profiles/details.cfm?co_id=RO.

33. European Commission. Food. Country profile-Slovakia [Internet]. [cited 2018 Dec 14]. Available from: http://ec.europa.eu/food/audits-analysis/ country_profiles/details.cfm?co_id=SK.

34. European Commission. Food. Country profile - Slovenia [Internet]. [cited 2018 Dec 14]. Available from: http://ec.europa.eu/food/audits-analysis/ country profiles/details.cfm?co id=SI

35. European Commission. Food. Country profile - Spain [Internet]. [cited 2018 Dec 14]. Available from: http://ec.europa.eu/food/audits-analysis/ country_profiles/details.cfm?co_id=ES.

36. European Commission. Food. Country profile - Sweden [Internet]. [cited 2018 Dec 14]. Available from: http://ec.europa.eu/food/audits-analysis/ country_profiles/details.cfm?co_id=SE.

37. European Commission. Food. Country profile - United Kingdom [Internet]. [cited 2018 Dec 14]. Available from: http://ec.europa.eu/food/ audits-analysis/country profiles/details.cfm?co id=GB.

Received October 5, 2016

Accepted in revised form December 14, 2018 